Informatika i sistemy upravleniya. - 2016. - No. 4(50). - P. 69-75.

Lapko A.V., Lapko V.A. (lapko@icm.krasn.ru)

Siberian State Aerospace University

\title{
STATISTICAL MODELS OF SPATIALLY DISTRIBUTED TEMPORAL PROCESSES
}

The technique of constructing statistical models of spatially distributed temporal processes, common in the study of environmental systems. The features of their synthesis and optimization in the conditions of homogeneous and heterogeneous environments.

Keywords: spatially distributed systems, statistical models, temporal processes, nonparametric models, decision rules.

DOI: $10.22250 /$ isu.2016.50.69-75

For citation:

Lapko A.V., Lapko V.A. STATISTICAL MODELS OF SPATIALLY DISTRIBUTED TEMPORAL PROCESSES // Informatika i sistemy upravleniya. - 2016. - No. 4(50). - P. 69-75. 